\title{
Tomasz Wiśniewski
}

Gdańsk

\section{Rosyjska konspiracja monarchistyczna w obozie internowania w Tucholi oraz w Toruniu w latach 1920-1922}

\begin{abstract}
Abstrakt: Artykuł omawia losy rosyjskich żołnierzy o przekonaniach monarchistycznych, internowanych w obozie w Tucholi oraz mieszkających w Toruniu. Bazując na policyjnych źródłach z Archiwum Państwowego w Bydgoszczy, przedstawia agitację monarchistyczną prowadzoną wśród internowanych oraz poza obozem. Obok opisu głównego przejawu aktywności grupy (kolportowanie prasy monarchistycznej pochodzącej głównie z Berlina) zasygnalizowana została międzynarodowa współpraca rosyjskiej emigracji monarchistycznej.
\end{abstract}

Słowa kluczowe: rosyjski monarchizm, Biała emigracja, Toruń, obóz internowania w Tucholi, Gdańsk.

Abstract: The article discusses the fate of Russian soldiers with monarchistic views who were interned in the camp at Tuchola and those who lived in Torun. On the basis of material kept in the State Archives in Bydgoszcz it presents monarchist agitation among internees in the camp and outside it. Aside from the description of a main activity of the group (distribution of the monarchist press, mainly from Berlin), there is also an outline of international cooperation of Russian monarchist emigration.

Keyw ords: Russian monarchism, White émigrés, Torun, Camps for Interned Russian soldiers at Tuchola, Gdańsk.

I wojna światowa położyła kres staremu porządkowi Europy. Boży pomazańcy, często w gwałtowny sposób ustępowali miejsca prezydentom, rządom tymczasowym czy innym republikańskim organom sprawowania władzy. Spełniły się marzenia wielu pokoleń różnych narodów. Austro-Węgry rozpadły się na 
wiele mniejszych państw, w miejsce Cesarstwa Niemieckiego powstała Republika Weimarska, Rosja zamieniła dwugłowego orła na czerwona gwiazdę. Odrodziła się Rzeczpospolita Polska. Kończący wojnę polsko-bolszewicka traktat ryski zmusił rząd polski do internowania swoich dotychczasowych, wschodniosłowiańskich sojuszników. Przeciwko bolszewizmowi, ramię w ramię z Wojskiem Polskim walczyli ochotnicy różnych narodowości. Ukraińcy, Białorusini czy Rosjanie opowiadając się w tym konflikcie po stronie polskiej, niekoniecznie walczyli za Polskę, raczej przeciwko bolszewikom i ich planom eksportu rewolucji.

Zagadnienia związane z działalnością rosyjskich monarchistów w II Rzeczypospolitej Polskiej nie doczekały się całościowego opracowania. Obecność orientacji monarchistycznej oraz jej agitację polityczną wśród internowanych sygnalizował Zbigniew Karpus w licznych artykułach poświęconych problematyce obozów internowania ${ }^{1}$. W tekstach tego badacza wspomniane zostały akcja monarchistyczna prowadzona w obozie w Tucholi oraz związki monarchistów rosyjskich zamieszkujacych Berlin, Paryż, Sofię². Oprócz działalności rosyjskich monarchistów w Wolnym Mieście Gdańsku, opisanej przez Andrzeja Romanowa w artykule dotyczącym rosyjskiej emigracji $\mathrm{w} \mathrm{WMG}^{3}$, tematyka ta jest zasadniczo obca polskiej historiografii. Ciekawe zagadnienie stanowią tradycyjne związki Cerkwi prawosławnej w Polsce z rosyjskim monarchizmem, manifestujące się $\mathrm{w}$ życiu parafialnym $\mathrm{np}$. sprawowaniem nabożeństw żałobnych za zmarłych pochodzących z rodziny carskiej czy mszy $\mathrm{w}$ intencji gen. Piotra Wrangla 4 . Zbadanie tej tematyki wydaje się istotne dla ustalenia, na ile idee monarchistyczne były żywotne w środowisku rosyjskich emigrantów, także wśród tych, którzy nie zostali wcześniej internowani. Podjęcie gruntownej kwerendy związanej z działalnością rosyjskich monarchistów w Polsce jest istotne w kontekście badań dziejów porewolucyjnej rosyjskiej

${ }^{1}$ Z. Karpus, Emigracja rosyjska, ukrainska i białoruska w Polsce w okresie międzywojennym (1918-1939). Stan badań i postulaty badawcze, w: Regiony pograniczne Europy Środkowo-Wschodniej w XVI-XX wieku. Spoteczeństwo, gospodarka, polityka, red. M. Wojciechowski, R. Schattkowsky, Toruń 1996, s. 93-100; idem, Jeńcy wojenni i emigracja polityczna $z$ Rosji na Pomorzu w latach 1914-1939 (procesy asymilacyjne, stosunek miejscowego społeczeństwa), w: Migracje polityczne i ekonomiczne w krajach nadbattyckich $w$ XIX $i$ XX $w$., red. J. Borzyszkowski, M. Wojciechowski, Toruń 1995, s. 125-136; idem, Obóz internowanych nr $7 \mathrm{w}$ Tucholi (wrzesień 1921 - styczeń 1923), w: Mniejszości narodowe i wyznaniowe $w$ województwie pomorskim w okresie międzywojennym (1920-1939), red. M. Wojciechowski, Torun 1991, s. 143-157; Tuchola. Obóz jeńców i internowanych 1914-1923, t. I, cz. 1, oprac. Z. Karpus, W. Rezmer, Toruń 1997.

${ }^{2}$ Z. Karpus, Obóz internowanych $n r 7 w$ Tucholi..., s. 151.

${ }^{3}$ A. Romanow, Emigracja rosyjska w Wolnym Mieście Gdańsku 1920-1939, „Rocznik Gdański” 1995, t. XLV, z. 2, s. 77-109.

${ }^{4}$ Z. Waszkiewicz, Stosunek administracji państwowej województwa pomorskiego i kurii biskupiej w Pelplinie do mniejszościowych zwiqzków wyznaniowych w latach 1920-1939, w: Mniejszości narodowe $i$ wyznaniowe $w$ województwie pomorskim..., s. 79; E. Alabrudzińska, Mniejszości wyznaniowe w Bydgoszczy w latach 1920-1939, Toruń 1995, s. 106. 
emigracji w Europie Środkowej i Zachodniej5. Jak zauważył Z. Karpus, Polska stanowiła „punkt przejściowy” dla wielu emigrantów z Rosji w dalszej drodze na zachód Europy ${ }^{6}$. Problematyka ta jest ważna także dla badań nad dziejami prawosławia, ponieważ wiele istniejących do dzisiaj parafii, zwłaszcza w diasporze (Polska Środkowa i Północna: Gdańsk, Bydgoszcz, Toruń), zostało założonych przez wiernych związanych ideowo z monarchizmem? ${ }^{7}$.

W niniejszym artykule pragnę przedstawić mały fragment dziejów emigracyjnego monarchizmu, skupiajac się na internowanych w obozie w Tucholi oraz w dużej mierze na Toruniu. Ze względu na zintensyfikowaną działalność policji, której dokumenty stanowią najważniejsze dla artykułu źródło, największy nacisk został położony na rok 1922. Do istotnego ze względu na swoja rangę ośrodka gdańskiego nie odnosiłem się szczegółowo, gdyż wystarczająco opracował go wspomniany już A. Romanow. Należy jednak zauważyć, że środowisko gdańskie nie zostało zbadane w wyczerpujacy sposób, czego dowodzi brak informacji o powiązaniach działaczy z WMG z obozem w Tucholi czy z Toruniem. Moim celem jest zainteresowanie historyków dziejami carskiego monarchizmu w Polsce, międzynarodowej współpracy rosyjskich kontrrewolucjonistów oraz $\mathrm{w}$ optymistycznym założeniu zachęcenie do prowadzenia badań w tymże kierunku naukowców z różnych ośrodków.

Pierwsze grupy emigrantów z Rosji pojawiły się w Polsce w listopadzie 1918 r., kiedy to Polska odzyskała niepodległość. Największa grupa Rosjan przybyła na Pomorze pod koniec grudnia $1920 \mathrm{r} .{ }^{8}$ Należeli do niej członkowie 3 Armii Rosyjskiej utworzonej w Polsce celem wspólnej walki z bolszewikami. Szeregi tej, dowodzonej przez Borysa Peremykina formacji zasilała największa liczba zwolenników monarchizmu9

Początkowo władze nie pozwalały na powstanie rosyjskich organizacji o charakterze politycznym, jednak już w 1919 r. w Warszawie rozpoczą działalność Rosyjski Komitet w Polsce ${ }^{10}$. Komitet ten nie mógł tworzyć oddziałów terenowych, co było spowodowane lękiem ze strony władz państwowych, dotyczacym wpływu ideologii monarchistycznej prezentowanej przez czołowych działaczy na całą rosyjską emigracjęPolsce. Sytuacja ta trwała aż do 1924 r. ${ }^{11}$,

${ }^{5}$ K. Halicki, Działalność policji politycznej w Wolnym Mieście Gdańsku w latach 1920-1939, „Policja. Kwartalnik Kadry Kierowniczej Policji” 2011, nr 4, s. 59-71; A. Romanow, op. cit.

${ }^{6}$ Z. Karpus, Emigracja rosyjska, ukrainska i białoruska..., s. 96.

${ }^{7}$ Zagadnienie to zasygnalizował w prywatnej rozmowie ks. Mikołaj Hajduczenia, proboszcz parafii prawosławnej św. Mikołaja Cudotwórcy w Toruniu, opinię tę podziela najstarsza generacja parafian.

8 Z. Karpus, Jeńcy wojenni i emigracja polityczna..., s. 128.

9 Archiwum Państwowe w Bydgoszczy (dalej: APB), Urząd Wojewódzki Pomorski, (dalej: UWP), sygn. 4871, Raport sytuacyjny z obozu internowanych w Tucholi za miesiąc kwiecień, k. 131.

${ }_{10}$ Archiwum Akt Nowych, Rosyjski Komitet w Polsce, sygn. 1.

${ }^{11}$ Mimo kilku prób nie udało się zarejestrować w Toruniu i Bydgoszczy żadnej organizacji rosyjskiej do 1924 r. (Z. Karpus, Życie społeczno-kulturowe mniejszości rosyjskiej w Bydgoszczy w okresie międzywojennym, „Kronika Bydgoska” 1991, t. XI, s. 116). 
kiedy to zostały ostatecznie uregulowane kwestie prawne emigrantów (przyznanie im „paszportów nansenowskich”). Władze polskie liczyły na zbliżenie ze środowiskiem rosyjskim ze względu na chęć wykorzystania go do walki z Rosja bolszewicka. Z powodu porozumienia zawartego między Józefem Piłsudskim a Borysem Sawinkowem, w lipcu 1920 r. powstał w Warszawie Rosyjski Komitet Polityczny. W obliczu wojny polsko-bolszewickiej sformowanych zostało kilka rosyjskich formacji sojuszniczych wobec strony polskiej: dowodzona przez Borysa Peremykina (ok. 12 tys. żołnierzy), kozackie (ok. 3 tys.) i gen. Stanisława Bułak-Bałachowicza ${ }^{12}$. Mimo politycznego podporządkowania tych formacji Rosyjskiemu Komitetowi Politycznemu, na czele którego stał Sawinkow, żołnierze różnych stopni wyznawali poglądy monarchistyczne, których przejawy wielokrotnie zaobserwowano $\mathrm{w}$ obozie internowania $\mathrm{w}$ Tucholi ${ }^{13}$. Po zakończeniu działań wojennych i podpisaniu traktatu brzeskiego oddziały te zostały przez stronę polską internowane. Rosjan umieszczono w Szczypiornie, Tucholi, Toruniu, Strzałkowie, Różanie ${ }^{14}$. Ostatni internowani odzyskali wolność do połowy 1924 r., kiedy to obozy zostały zlikwidowane ${ }^{15}$. Populacja rosyjska w Polsce liczyła w tym czasie ok. 10 tys. osób ${ }^{16}$.

Rosyjscy monarchiści przebywajaccy na terenie województwa pomorskiego najbardziej przejawiali inicjatywę w 1922. Z tego roku pochodzi najwięcej doniesień o ich aktywności w obozie internowania w Tucholi. Dzięki działalności konfidentów policji udało się wpaść na trop zorganizowanej akcji monarchistycznej z rozległymi kontaktami międzynarodowymi, a także stworzyć obszerną listę osób związanych z agitacją rojalistyczną ${ }^{17}$. Według ustaleń policji monarchiści rosyjski byli zrzeszeni w komitecie „Prawlenie sojuza wzajimnoj pomoszczy oficerow bywszych rosyjskich armii i floty”"18, którego filię w obozie w Tucholi założyli Modest Karamyszew i Arwit Kahn, byli żołnierze z formacji gen. Wrangla ${ }^{19}$. Do tucholskiej ekspozytury należało 77 znanych z nazwiska osób $^{20}$. Organizacja ta powstała z inicjatywy gen. Nowikowa w Gdańsku, na

${ }^{12}$ Idem, Emigracja rosyjska, ukraińska i białoruska..., s. 97.

${ }^{13}$ Wśród byłych żołnierzy Dywizji Strzelców gen. Borysa Peremykina monarchiści stanowili 85\% grupy (UWP, sygn. 4871, Raport sytuacyjny z obozu internowanych w Tucholi za miesiąc kwiecień, k. 131), poparcie dla monarchizmu wśród „Bałachowców” gen. Stanisława Bułak-Bałachowicza oszacowano na 60\% składu (ibidem, k. 127), dla byłej Wolnej Dywizji Kozackiej dane nie sa tak dokładne (ibidem, k. 131).

${ }^{14}$ Z. Karpus, Emigracja rosyjska, ukraińska i białoruska..., s. 97.

15 Ibidem.

${ }^{16}$ Ibidem, s. 98.

${ }_{17}$ APB, Komenda woj. P.P. w Toruniu, sygn. 304, Organizacja monarchistyczna w obozie w Tucholi, k. 17-18.

${ }_{18}$ Pisownia oryginalna z dokumentów wytworzonych przez Komendę Wojewódzką w Toruniu.

19 APB, Komenda woj. P.P. w Toruniu, sygn. 58, k. 8.

${ }^{20}$ APB, Komenda woj. P.P. w Toruniu, sygn. 304, Organizacja monarchistyczna w obozie w Tucholi, k. 17-18. 
jej czele stał gen. Lebiediew ${ }^{21}$. Celem komitetu były: integracja wszystkich Rosjan, zwolenników idei monarchistycznej, moralna i finansowa opieka nad nimi oraz przeprowadzenie $\mathrm{w}$ dogodnym momencie przewrotu rojalistycznego w Rosji ${ }^{22}$. Agitatorzy w obozie otrzymywali swoje wynagrodzenie za pośrednictwem YMCA ${ }^{23}$. Prawie wszyscy znani z nazwiska monarchiści deklarowali się jako wyznawcy prawosławia, warto jednak zauważyć, że jeden z dwóch głównych działaczy, A. Kahn, urodzony w łotewskiej Mitawie, był ewangelikiem ${ }^{24}$. Gdański komitet „Prawlenie sojuza wzajimnoj pomoszczy oficerow bywszych rosyjskich armii i floty” utrzymywał ożywione kontakty z berlińskim „Wierchowym monarchiczewskim komitetem” oraz z organizacja „Russki Sowiet” z Belgradu ${ }^{25}$. Podczas rewizji przeprowadzonej wśród internowanych w Tucholi znaleziono wydawane w Berlinie pisma: „Ster”, „Najwyższa Monarchiczewska Rada” oraz „Dwugłowy Orzeł”26. Monarchistyczni agitatorzy pragnęli w różny sposób propagować swoje idee wśród współosadzonych. Wobec rosnącej liczby zwolenników powrotu do Rosji bolszewickiej oficerowie monarchiści próbowali utrzymywać dyscyplinę i gotowość bojową wśród żołnierzy ${ }^{27}$. Grupa ta prowadziła także warsztaty wyrobów artystycznych, koszyków i zabawek ${ }^{28}$. Według popularnej w obozie plotki, umiejętnie podsycanej przez koła kontrrewolucyjne, wśród internowanych przebywał cudem ocalony cesarzewicz Aleksy, który podzielając trudny los ludu, cierpiał, aby tym bardziej zasłużyć na koronę ${ }^{29}$. Idee monarchistyczne były szczególnie popularne wśród „elementu najinteligentniejszego", w największym stopniu arystokracji ${ }^{30}$. Ratunku dla Rosji, rozumianego jako powrót monarchii, upatrywano m.in. w sojuszu z Niemcami. Współpraca ta była podejmowana przy pomocy „rosyjskich Niemców” i polegała w obozie na kontaktowaniu się z ludnością niemiecką Tucholi ${ }^{31}$.

${ }^{21}$ Ibidem, k. 11.

${ }^{22}$ Ibidem.

${ }^{23}$ Ibidem, k. 12. YMCA (Young Men's Christian Association) - Związek Chrześcijańskiej Młodzieży Męskiej - organizacja powstała w 1844 r. w Londynie, oparta na chrześcijańskich ideach, propagujacca rozwój duchowy i fizyczny. W odrodzonej Rzeczypospolitej zwiąek funkcjonuje od $1918 \mathrm{r}$. W Polsce członkowie YMCA zajmowali się początkowo organizacja wydarzeń kulturalnych, opieka i prowadzeniem sklepów dla żołnierzy. (T. Tlustý, The YMCA organisation and its physical education and sports activities In Europe Turing the First World War, „Prace Naukowe Akademii im. Jana Długosza w Częstochowie. Kultura Fizyczna” 2015, t. XIV, nr 1, s. 27-44).

${ }^{24}$ APB, Komenda woj. P.P. w Toruniu, sygn. 304, Akt oskarżenia, k. 29.

${ }^{25}$ Ibidem, Organizacja monarchistyczna w obozie w Tucholi, k. 11.

${ }^{26}$ Ibidem, k. 12.

${ }^{27}$ APB, UWP, sygn. 4871, Raport sytuacyjny z obozu internowanych w Tucholi za miesiąc kwiecień, k. 135.

${ }_{28}$ Z. Karpus, Obóz internowanych nr $7 w$ Tucholi..., s. 151.

${ }^{29}$ APB, UWP, sygn. 4871, Raport sytuacyjny z obozu internowanych w Tucholi za miesiąc kwiecień, k. 135.

${ }^{30}$ Ibidem, k. 131.

${ }^{31}$ Ibidem, k. 135. 
W maju 1922 r. zatrzymani zostali kurierzy organizacji, przerzucajaccy prasę i rozkazy gen. Nowikowa z Gdańska do Tucholi. Byli to Żydzi Mendel Fuchs i Szlem Szpak ${ }^{32}$. Ponadto ustalono tożsamość kolejnego łącznika, Izaaka Weinera, posługującego się także nazwiskami Ginzberg i Kuzniecow. Weiner był oficerem z formacji Denikina, byłym internowanym, któremu udało się zbiec ${ }^{33}$. Oprócz tego pilną korespondencję z Gdańska komitet wysyłał na adres mieszkającego w Tucholi, przy ul. Ceglanej 9, Niemca Alberta Bütnera ${ }^{34}$. Dekonspiracja wyżej wymienionych kurierów została zaraportowana jako częściowa likwidacja organizacji monarchistycznej w obozie ${ }^{35}$, jednak już w czerwcu pojawili się nowi posłańcy: płk Mikołaj Zagulajew i wymieniany tylko z nazwiska Nikiforow ${ }^{36}$.

Równolegle do agitacji prowadzonej w obozie, w Toruniu i częściowo w Bydgoszczy działał Borys Iwanowicz Tymoszczenko. Rewizja dokonana $19^{37}$ lub $20^{38}$ maja w toruńskich koszarach 18 Pułku Ułanów Pomorskich, gdzie mieszkał Tymoszczenko, wykazała jego związki z monarchistami rosyjskimi z Gdańska, Paryża, Berlina, Bułgarii ${ }^{39}$. Jako były pułkownik armii gen. Wrangla Tymoszczenko posiadał duży wpływ na rosyjską społeczność Torunia. Mimo braku zgody władz państwowych na istnienie w Toruniu organizacji rosyjskiej, wyniki rewizji pozwoliły stwierdzić, że Tymoszczenko pełnił funkcję przedstawiciela Rosyjskiego Komitetu w Toruniu ${ }^{40}$. Były pułkownik utrzymywał bliskie stosunki z kierownikiem orkiestry rosyjskiej, ppłk. Sergiuszem Głuszkowem, u którego także przeprowadzono rewizję ${ }^{41}$. W obu mieszkaniach znaleziono oprócz korespondencji prasę monarchistyczna, kolportowaną także wśród internowanych, ponadto Tymoszczence zarekwirowano prowizoryczna mapę ilustrująca położenie wojsk gen. Wrangla na Bałkanach ${ }^{42}$. W związku z uznaniem Tymoszczenki i Głuszkowa za stojacych na czele agitacji monarchistycznej w Toruniu policja wystosowała wniosek do prezydenta miasta z prośba o ponowne internowanie wyżej wymienionych jako uciążliwych obcokrajowców ${ }^{43}$.

20 maja dokonano przeszukań kolejnych toruńskich mieszkań zamieszkałych przez Rosjan. Rewizja lokalu YMCA, przy ul. Jana Kochanowskiego ${ }^{44}$,

\footnotetext{
${ }^{32}$ Ibidem, Raport sytuacyjny z obozu internowanych w Tucholi za miesiąc maj, k. 263.

${ }^{33}$ Ibidem, Dalsze dane o organizacji monarchistycznej w Tucholi, k. 81.

${ }^{34}$ Ibidem.

${ }^{35}$ Ibidem, Raport sytuacyjny z obozu internowanych w Tucholi za miesiąc maj, k. 263.

${ }^{36}$ Ibidem, Raport sytuacyjny z obozu internowanych w Tucholi za miesiąc czerwiec, k. 303.

${ }^{37}$ Ibidem, Raport sytuacyjny z obozu internowanych w Tucholi za miesiac lipiec, k. 421.

${ }^{38} 20$ maja wydaje się bardziej prawdopodobny, ponieważ tego dnia dokonano rewizji w mieszkaniach innych Rosjan podejrzewanych o sympatie monarchistyczne (ibidem, Rewizje $\mathrm{u}$ internowanych zamieszkałych w Toruniu (monarchiści), k. 612).

${ }^{39}$ Ibidem, Sprawa monarchistów rosyjskich, k. 387.

${ }^{40}$ Ibidem.

${ }^{41}$ Ibidem.

${ }^{42}$ Ibidem, Kopia mapy z rozmieszczeniem wojsk rosyjskich, k. nlb.

${ }^{43}$ Ibidem.

${ }^{44}$ APB, UWP, sygn. 4872, Przeprowadzenie rewizji w mieszkaniu stowarzyszenia YMCA, k. nlb.
} 
w którym mieszkali Jerzy Tereszczenko oraz Bazyli Żelichowski, wykazała utrzymywanie kontaktów listownych z zagranicznymi ośrodkami monarchistycznymi, podobnie jak w przypadku Tymoszczenki ${ }^{45}$. Ponadto dokonano rewizji w mieszkaniu Jana Jarcewa, przyjaciela Borysa Tymoszczenki ${ }^{46}$. Ustalono także, że ostatni utrzymywał kontakty z byłymi carskimi oficerami służącymi w Wojsku Polskim, zwłaszcza ze Spirydionem Koiszewskim, ułanem z Ostrołęki, od którego dostawał pieniądze ${ }^{47}$.

Trzy dni później w czasie przesłuchania Tymoszczenko przyznał, że otrzymał w ramach zapomogi pieniądze od Koiszewskiego, miał kontakt z Rosyjskim Komitetem w Warszawie i pobrał od niego środki finansowe na założenie filii tejże organizacji w Toruniu, co jednak wobec sprzeciwu władz wojewódzkich nie zostało wykonane ${ }^{48}$. Według przesłuchiwanego znaleziona prasa monarchistyczna należała do byłego współlokatora Iwanowa, który wyjechał na stałe do Gdańska. Ponadto Tymoszczenko oświadczył, że nie jest członkiem żadnej rosyjskiej organizacji politycznej ${ }^{49}$.

Osoby zaangażowane w działalność monarchistyczną w obozie w Tucholi zostały oskarżone o założenie ukrywanego przed władzami polskimi związku o charakterze politycznym oraz przyrzeczenie posłuszeństwa nieznanym zwierzchnikom ${ }^{50}$. Głównymi oskarżonymi byli M. Karamyszew i A. Kahn, których wskazano jako założycieli organizacji „Prawlenie sojuza wzajimnoj pomoszczy oficerow bywszych rosyjskich armii i floty" w obozie ${ }^{51}$. Rozprawa odbyła się 28 IX 1922 r. w Chojnicach ${ }^{52}$, oskarżonych ku zaskoczeniu policji uniewinniono ${ }^{53}$. Monarchiści rosyjscy, zarówno internowani, jak i przebywajacy w Toruniu, utrzymywali kontakty z rosyjską emigracją w Gdańsku. Według oceny A. Romanowa w latach 1920-1925 w rosyjskim życiu politycznym Gdańska najsilniej reprezentowany był ruch monarchistyczny ${ }^{54}$. Podobnie jak w innych dużych ośrodkach emigracyjnych, funkcjonowało wiele różnych stronnictw politycznych, także wśród samych rojalistów. Najbardziej zasadne kryterium podziału rosyjskich ugrupowań monarchistycznych w WMG opiera się na ich koncepcjach „polityki zagranicznej”55. Monarchiści, tacy jak Borys Tymoszczenko czy internowani działacze, których nazwiska znalazły się na

${ }^{45}$ Ibidem, Rewizje u internowanych zamieszkałych w Toruniu (monarchiści), k. 612.

${ }^{46}$ Ibidem.

${ }^{47}$ Ibidem, k. 613.

${ }^{48}$ Ibidem, Protokół przesłuchania Borysa Iwanowicza Tymoszczenko, k. nlb.

${ }^{49}$ Ibidem.

50 APB, Komenda woj. P.P. w Toruniu, sygn. 304, k. 32.

${ }^{51}$ Ibidem.

${ }^{52}$ Ibidem, k. 28.

${ }^{53}$ Ibidem, k. 33.

${ }^{54}$ A. Romanow, op. cit., s. 84.

${ }^{55}$ Podział taki przyją Krzysztof Halicki w artykule dotyczącym działalności policji politycznej w WMG. Zob. K. Halicki, op. cit., s. 59-71. 
liście sporządzonej przez Komendę Wojewódzką Policji w Toruniu ${ }^{56}$, utrzymywali kontakty z „frakcją niemiecką”. Z opcją tą łączyły ich osoby generałów Lebiediewa i Nowikowa, współpracujących z berlińskim Związkiem Oficerów Rosyjskich ${ }^{57}$. Generałowi Nowikowowi, już po wygaśnięciu działalności monarchistów rosyjskich w Toruniu i Bydgoszczy, powierzono przygotowanie planów zbrojnych akcji dywersyjnych na pograniczu radzieckim, mających być prowadzonymi z terenów Estonii i Litwy ${ }^{58}$. Misję tę Nowikow otrzymał podczas narady gdańskich monarchistów m.in. z gen. Wranglem, jaka miała miejsce $\mathrm{w}$ sopockim hotelu „Reichsadler” $\mathrm{w}$ grudniu $1924 \mathrm{r} .{ }^{59} \mathrm{~W}$ tymże roku liczba rosyjskich monarchistów była szacowana na 1200 osób, co czyniło z Gdańska największy ośrodek carskiego monarchizmu w centralnej Europie ${ }^{60}$. Po raz ostatni nazwisko gen. Nowikowa pojawiło się w związku z jego wydaleniem z WMG, na wniosek konsula generalnego ZSRR w tymże mieście ${ }^{61}$. Kres zintensyfikowanej działalności gdańskich monarchistów przypadł na rok $1929^{62}$. Gdańskie, profrancuskie ugrupowania monarchistyczne nie miały większego wpływu na rosyjskich monarchistów na omawianym terenie.

Po likwidacji obozu internowania w Tucholi w listopadzie $1922 \mathrm{r}^{63}$ oraz po przeprowadzeniu rewizji w mieszkaniach toruńskich działaczy losy rosyjskich monarchistów sa nieznane. Brak doniesień o działalności carskich rojalistów w raportach policyjnych, przechowywanych w Archiwum Państwowym w Bydgoszczy, pozwala wyciagnąc wniosek o opuszczeniu przez nich granic województwa pomorskiego. Romanow opisując w cytowanym wcześniej artykule gdańskie środowisko rosyjskich monarchistów, nie wymienił nazwisk byłych internowanych. Wobec wrogiej komunizmowi postawy monarchistów wydaje się mało prawdopodobny ich powrót do Rosji, należy raczej brać pod uwagę zasilenie przez nich szeregów „białej emigracji” Sofii, Berlina i Paryża ${ }^{64}$. Rekonstrukcja dalszych losów wspomnianych monarchistów będzie możliwa po dokonaniu kwerendy archiwalnej w wyżej wymienionych stolicach.

${ }^{56}$ APB, Komenda woj. P.P. w Toruniu, sygn. 304, Organizacja monarchistyczna w obozie w Tucholi, k. 17-18.

57 A. Romanow, op. cit., s. 86.

${ }^{58}$ Ibidem, s. 87.

${ }^{59}$ Ibidem.

${ }^{60}$ K. Halicki, op. cit., s. 68.

${ }^{61}$ A. Romanow, op. cit., s. 92.

${ }^{62}$ Ibidem, s. 93.

${ }^{63}$ Jako dwa główne kierunki migracji Karpus wymienił Francję oraz Brazylię (Z. Karpus, Rosjanie i Ukraińcy na Pomorzu w latach 1920-1939, w: Mniejszości narodowe i wyznaniowe na Pomorzu $w$ XIX i XX wieku, red. M. Wojciechowski, Toruń 1998, s. 102). Wobec utrzymywania korespondencji z emigracją niemiecką i bułgarską można potencjalnie przyjmować te kierunki migracji za prawdopodobne.

${ }^{64}$ Ibidem. 


\section{Streszczenie}

Wobec wybuchu rewolucji bolszewickiej i wojny domowej w Rosji na terenie Rzeczypospolitej Polskiej znalazło się wielu rosyjskich emigrantów. W związku z zawarciem traktatu ryskiego rząd polski internował wielu spośród swoich dotychczasowych sojuszników, wśród których przywiązaniem do monarchii wyróżniali się członkowie 2 Armii Rosyjskiej, dowodzonej przez Borysa Peremykina. Na terenie obozu internowania w Tucholi oraz w Toruniu policja wykryła działalność komitetu „Prawlenie sojuza wzajimnoj pomoszczy oficerow bywszych rosyjskich armii i floty", którego członkowie kolportowali wśród współosadzonych kontrrewolucyjna prasę oraz utrzymywali nastrój gotowości do podjęcia dalszej walki z bolszewizmem. O konieczności tej walki miał świadczyć pobyt w Tucholi domniemanego cesarzewicza Aleksego, dzielącego niedole internowania wiernych swojej rodzinie żołnierzy. Krótko po rozwiązaniu obozu internowania w Tucholi, w 1922 r. działalność rosyjskich monarchistów w Toruniu zamarła, co zapewne było spowodowane zasileniem przez nich szeregów „białej emigracji” Berlina, Sofii lub Paryża.

\section{Russian monarchistic underground in the internment camp at Tuchola and in Torun in 1920-1922}

The outbreak of the Bolshevik revolution and civil war in Russia caught many Russian émigrés in the territory of the Polish Republic. After the Treaty of Riga the Polish government interned many of its former allies, among whom a special attachment to monarchy displayed the members of the Second Russian Army commanded by Boris Peremykin. In the Tuchola internment camp and in Torun the police uncovered activities of the committee called The Board of the Union for Mutual Aid of Former Officers of the Russian Army and Fleet, the member of which circulated the counter-revolutionary press among the inmates and maintained a state of readiness to fight against Bolshevism. The necessity of this struggle was being justified by the fact that one of the internees at Tuchola was the alleged tsarevitch Alexy, who shared the misery of his family's faithful soldiers. Soon after the dissolution of Tuchola camp, in 1922, activities of Russian monarchists in Torun ceased, probably because they left for Berlin, Sofia or Paris, to join there the ranks of "White emigration".

\section{Bibliografia}

Alabrudzińska E., Mniejszości wyznaniowe w Bydgoszczy w latach 1920-1939, Toruń 1995. Halicki K., Działalność policji politycznej w Wolnym Mieście Gdańsku w latach 1920-1939, „Policja. Kwartalnik Kadry Kierowniczej Policji” 2011, nr 4, s. 59-71.

Karpus Z., Emigracja rosyjska, ukrainska i białoruska $w$ Polsce $w$ okresie międzywojennym (1918-1939). Stan badań $i$ postulaty badawcze, w: Regiony pograniczne Europy Środkowo-Wschodniej w XVI-XX wieku. Społeczeństwo, gospodarka, polityka, red. M. Wojciechowski, R. Schattkowsky, Toruń 1996, s. 93-100.

Karpus Z., Jeńcy wojenni i emigracja polityczna $z$ Rosji na Pomorzu w latach 1914-1939 (procesy asymilacyjne, stosunek miejscowego społeczeństwa), w: Migracje polityczne $i$ ekonomiczne $w$ krajach nadbattyckich $w$ XIX $i$ XX w., red. J. Borzyszkowski, M. Wojciechowski, Torun 1995, s. 125-136.

Karpus Z., Obóz internowanych nr 7 w Tucholi (wrzesień 1921 - styczeń 1923), w: Mniejszości narodowe $i$ wyznaniowe $w$ województwie pomorskim $w$ okresie międzywojennym (1920-1939), red. M. Wojciechowski, Toruń 1991, s. 143-157. 
Romanow A., Emigracja rosyjska w Wolnym Mieście Gdańsku 1920-1939, „Rocznik Gdański” 1995, t. XLV, z. 2, s. 77-109.

Tlustý T., The YMCA organisation and its physical education and sports activities In Europe Turing the First World War, „Prace Naukowe Akademii im. Jana Długosza w Częstochowie. Kultura Fizyczna” 2015, t. XIV, nr 1, s. 27-44.

Tuchola. Obóz jeńców i internowanych 1914-1923, t. I, cz. 1, oprac. Z. Karpus, W. Rezmer, Toruń 1997.

Waszkiewicz Z., Stosunek administracji państwowej województwa pomorskiego i kurii biskupiej w Pelplinie do mniejszościowych zwiqzków wyznaniowych w latach 1920-1939, w: Mniejszości narodowe $i$ wyznaniowe $w$ województwie pomorskim $w$ okresie międzywojennym (1920-1939), red. M. Wojciechowski, Toruń 1991, s. 73-95.

Biogram: Tomasz Wiśniewski - mgr; doktorant Wydziału Historycznego UG. Interesuje się problematyką narodowościową w Cerkwi prawosławnej i greckokatolickiej w II RP oraz działalnością ugrupowań monarchistycznych. Autor artykułów: Uniwersalizm Cerkwi Prawosławnej w II RP a problem „Polaków Prawosławnych”, „Postscriptum Polonistyczne” 2015, t. IV, s. 415-423; Sytuacja ludności żydowskiej podczas rosyjskiej okupacji Przemyśla i Lwowa w 1914-1915 roku w świetle pamiętników, „Kwartalnik Historii Żydów” 2013, nr 4 (248), s. 635-647. E-m ail: wisniewski.tomaszk@gmail.com. 